Article

\title{
Policy on Religion in the European Union
}

\author{
Piotr Mazurkiewicz
}

Institute of Political Science and Public Administration, Cardinal Stefan Wyszynski University, 01-815 Warsaw, Poland; p.mazurkiewicz@uksw.edu.pl

Received: 9 September 2020; Accepted: 10 October 2020; Published: 19 October 2020

\begin{abstract}
The main idea of article is that, even if EU has no competence in religious matters, what we can observe now is a creation of a very specific policy on religion. (1) Herein, I explain why the EU is interested in religion and how it is improving its competence with respect to it. Mostly, this is achieved by a transformation of religious matters into secular ones, falling under EU competences. I consider how the EU is treating religious matters in its primary and secondary law. Then, migration and accession policy are analyzed from the point of view of results for the religious structure of the European societies. Next, the issue of religion in the EU external policy is shortly studied as well as the impact of ECtHR and the European Court of Justice-ECJ jurisprudence on religious communities. Finally, we have a description of res novae in the EU approach to religion. The article adopts the Catholic perspective. This applies both to anthropology and to the institutional aspect. (2) The main methods used in the paper are analytical-synthetic and the analysis of legal texts. (3) We can justly talk about the EU policy on religion in statu nascendi. This policy is organized differently than at the nation-states level. (4) EU politicians need churches and religious communities to legitimize their political decisions and the integration process in general. They are tempted to "domesticate" religions and religious leaders and change religions from within. In this way, the political world subjugates the world of religion and takes control of it, which may result in a new kind of politics and legal resacralization.
\end{abstract}

Keywords: religion; European Union; Catholic Church; policy on religion; art 17 of TFUE

\section{What Is Policy on Religion?}

What is policy on religion? Although we use this concept relatively often, especially in post-communist countries in which dedicated ministries or their confessional departments existed, generally when someone speaks on this matter, one does not speak about policy but about law on religion, i.e., the law regarding religion, religious communities, and religious institutions. The law, however, is something different than policy. It is, in a sense, a tool, and the fruit of policy. Therefore, we create law in order to achieve certain political goals, and at the same time, we use law as one of the instruments of political action. Thus, if policy is a conscious action striving to achieve goals that directly or indirectly concern the life of the polis, i.e., a political community (in the etymological sense), then the law is only its element in the above sense.

If the state were to pursue policy on religion, i.e., policy regarding religious communities and institutions, the question arises about the reasons for, and objectives of such action. In other words, why should the state be interested in religion and religious communities at all? It seems that at least five reasons for such interest can be enumerated. Firstly, there exist theocratic countries in the world, in which policy is treated (at least theoretically) as a tool for realizing God's will and a help in bringing their subjects to salvation. Secondly, we had and have ideological countries in the world (e.g., China or North Korea) in which the given ideology plays the role of a "secular religion". Any other religion in this situation is the competition in the struggle for the "souls" of citizens. The existence of any institutions, including religious ones, which would not be subject to state control, is also unacceptable. 
Therefore, the state is interested in religion in order to "neutralize" it. Thirdly, ever since Plato's time, religion has been seen as one of the potential instruments of political action. Plato did not mean that religious leaders could set themselves political goals, but on the contrary: he was convinced that the state could not be governed without reference to religious motivation. Religion gives political power legitimacy, and at the same time motivates people to obey despite the fact that this power does not promise perfect justice, for a religious man knows that this is meted out by the gods in another aeon. We are dealing here with an attempt by the state to instrumentalize religion for political purposes, which can be done in good or bad faith, although in both cases it is an offense against religious freedom. ${ }^{1}$ Fourthly, a multicultural state may perceive religion as a source of potential social conflict. Therefore, it may be afraid of something like "religious wars" between religiously diverse sectors of society, or the melting of religion and some ideology considered dangerous, such as religious fundamentalism or nationalism. Feeling responsible for social peace, the state may want to take action aimed at establishing or maintaining it. It seems that nowadays in Europe this is the main reason for the state's interest in Islam, as it is the religion of the majority of immigrants arriving on the Old Continent. Here, an important question arises about the ability of European societies to integrate new arrivals and about the willingness of immigrants themselves to become part of Western society. Fifthly, the state may perceive religion as one of the essential elements of the common good. A little American style, it may be interested in people being religious, but without supporting any particular religion. This list is certainly not exhaustive.

The question arises as to what substantive competences the state has to deal with religion at all. In the first case, the state, most often due to some form of integration of spiritual leaders into political institutions, considers itself an expert, most often the best expert in religious and political matters. In the second and third cases, the state deems the above question explicitly or implicitly irrelevant, i.e., actually performs the act of usurpation. In the fourth and fifth cases, it can be expected that this question will be dealt with by the state with due seriousness. In fact, this is not always the case. Still, it is worth trying to describe the nature of the problems we face in these cases.

First, to deal with religion competently, one must answer the question of what religion is. Even when it comes to the etymology of the word, the matter is not clear whether it comes from relegere or from religare. ${ }^{2}$ The question also arises whether it is right to use the same term "religion" for phenomena as diverse as animism, Hinduism, Buddhism, Confucianism, Islam, Judaism, and Christianity. Are faith in personal and impersonal god(s), monotheistic and polytheistic beliefs, or referring to transcendence and "intra-worldliness" focused on dogma and concentrated on rituals? Aware of the incompatibility of these such different phenomena, some thinkers came to conclusion that Christianity is not a religion, or is a religion that goes beyond the concept of religion (la religion de la sortie de la religion) (Marion 2017, pp. 74-77). Others concluded that Christianity is the sole religion that it is a religion only, while other beliefs are something else, as they have some additional, non-religious element built in. ${ }^{3}$

1 Let us recall that, for example, The Aeneid was written by Virgil on the order of Octavian Augustus to assign a divine origin to the emperor's family (gens Julia), deriving him from the goddess Venus and the Trojans.

2 In the interpretation of the term 'religion', already in the case of the Latin roots of the word, two approaches can be seen. Cicero derives the word religio from relegere, which means: re-gather together, rethink something, read something again, repeat, follow the same path. Hence, the religiosi are people, who try to carefully observe and repeat everything that concerns the gods. "They who diligently perused and, as we may say, read and practiced over again all the duties relating to the worship of the gods were called religiosi; ( ... ) as elegantes, elegant, ex eligendo, from choosing, or making a good choice" (Cicero 1829, 2,28, p. 107). Religion understood in this way is above all a set of beliefs and practices related to gods, specific to a given nation and transmitted by tradition. Re-reading is associated with the use of reason; hence, religio can also be seen as the opposite of superstitio-superstition. Early Christianity associated more often the word "religion" with re-ligare, reconnect, referring, first, to connecting man with God (and not with the tradition), and subsequently the believers among themselves. " (...) man is bound to God by the ties of piety, whence religion itself receives its name" (Lactantius 1886, VI,28, p. 382; see also: Kłoczowski 2004, p. 1063). Religion, therefore, is based on man's personal relationship with God, which is realized in the Church's community. The Risen Christ is the only Mediator between the Father and people (Mazurkiewicz 2017a, pp. 95-100).

3 Rémi Brague points out that the meaning of the word "religion" was shaped in a Christian context. Therefore, it fully refers to Christianity, which as the only of the great religions is solely a religion, and therefore an action focused on connecting man with God. Brague refers here to Hegel, who calls Christianity the "absolute religion" (ab-solutum), i.e., not containing 
If there is ambiguity in defining this phenomenon, both in terms of philosophy and theological debates, then how would the state know what religion is and what it should be? The recognition of the incompetence of the state in this area is the basic premise underlying the idea of the separation of state and religion. This thesis should also be considered true when it was demanded-as in the case of John Locke-in the name of social peace. Locke does not promote the idea of a crypto-religious state that, due to social agreement, conceals its religious preferences. What he means is recognizing that beliefs that do not have an impact on social life are not relevant from the point of view of state power and, therefore, should be removed from the field of political disputes. ${ }^{4}$ The idea of tolerance understood in this way implicitly believes that, at least in the said area of doctrinal disputes, state authority is not competent. It does not know, therefore, which religious doctrine is more effective when it comes to the possibility of getting to heaven (Locke 1983).

Jean-Luc Marion proposes that Pascal's distinction of the "three orders" be used to explain the causes of state incompetence. In his "Thoughts", Pascal clearly distinguishes the "order of the flesh" (l'ordre de la chair), the "order of the mind" (l'ordre de l'esprit), and the "order of the heart" (l'ordre du coeur). These orders are infinitely distant from one another and radically different, such that people living in one of them do not need what is considered great in the other, and do not understand what this greatness is about. "The greatness of clever men is invisible to kings, to the rich, to chiefs, and to all the worldly great. The greatness of wisdom, which is nothing if not of God, is invisible to the carnal-minded and to the clever. These are three orders differing in kind" (Pascal 1958, 792, p. 234). Pascal sees these three orders as hierarchically arranged (Manon 2009). Therefore, the carnal-minded have their temporal kingdom in which power, wealth, and other temporal goods are valued. "Great geniuses have their power, their glory, their greatness, their victory, their lustre, and have no need of worldly greatness, with which they are not in keeping. ( ... ) The saints have their power, their glory, their victory, their lustre, and need no worldly or intellectual greatness, with which they have no affinity; (...). They are seen of God and the angels, and not of the body, nor of the curious mind. God is enough for them." (Pascal 1958, 792, p. 234). The self-sufficiency of the inhabitants of the "kingdom of holiness" stems from the fact that "All bodies together, and all minds together, and all their products, are not equal to the least feeling of charity. This is of an order infinitely more exalted." (Pascal 1958, 792, p. 235). The tyranny of state power-according to Pascal-"consists in the desire of universal power beyond its scope." (Pascal 1958, 332, p. 94). Therefore, whoever, having power in one sphere, tries to extend it to other orders outside his competence, deserves only the name of usurper. "Tyranny is the wish to have in one way what can only be had in another." (ibid). Therefore, the basis of the properly understood principle of separation of state and religion is the state recognizing its incompetence in the religious field and giving up any attempts to usurp. State power belongs to a different order.

It seems that this way of explication needs to be slightly nuanced. Even though the state does not know what religion is, it does not follow that among state officials no one knows it. After all, among them there are also religious people. Their knowledge and religious sense somehow translate into the functioning of the state, although they do not extend to it any additional competence. This state could be called docta ignorantia-learned ignorance, with learnedness rooted in individuals as private persons. ${ }^{5}$ Therefore, the state, using the resources of private knowledge of its officials, knows at least where it is not competent, which means that at the interface of these two areas it does not have to move like a bull in a china shop. Secondly, since the School of Salamanca, we have known that between the two spheres, temporal and spiritual, there spreads the area of so-called mixed matters

any addition of other aspects. Other great religions "add" to the religious an additional element. For example, Judaism denotes religion and nation or religion and morality, Islam-religion and legal system, and Buddhism-if it can be called religion-adds a doctrine of wisdom. This means that the term "religion" is not adequate not only in relation to the so-called secular religions, but also in relation to other great religions, though for another reason (Brague 2018, pp. 11-42).

4 In the case of Catholicism and atheism, Locke proposes a complete ousting of such attitudes from social life.

5 Est ergo in nobis quaedam, ut dicam, docta ignorantia, sed docta spiritu dei, qui adiuvat infirmitatem nostram (Augustine 1887, 130, c. $15, \S 28)$. 
(res mixtae), the management of which is a concerted decision of both authorities: spiritual and secular. Over time, this led to the development in Europe of a model of autonomy, independence, and healthy cooperation between the institutions of the state and the Church, as enshrined, for example, in the Council Constitution Gaudium et Spes ${ }^{6}$.

\section{The Specificity of EU's Policy on Religion}

Thinking of the European Union as a political body, we are facing another difficulty. It is undoubtedly an international organization, but with a very specific status, with a much broader scope of competence vis-à-vis its member states. We say that it is sui generis, or one of a kind. Therefore, unlike the member states, it does not enjoy a presumption of competence arising from the principle of state sovereignty. It only has as many competences as the member states have explicitly delegated to it, and these competences are exercised jointly, whatever that may mean.

When answering the question regarding the Union's competences in the religious field, it must be said that it has far fewer than any member state. However, this is not only a presumption based on the fact that the member states did not transfer any power in this area, but a claim firmly established in EU primary law. This was expressed positively first in the so-called Amsterdam Declaration, and then in Art. 17 of the Treaty on the Functioning of the European Union, where in paragraph 1 we read: "The Union respects and does not prejudice the status under national law of churches and religious associations or communities in the Member States." This sentence should be interpreted primarily in a negative sense. If political entities in Europe have any competence to create law regarding religion, it is reserved only for the member states. It can be concluded from some acts of secondary law that the EU institutions do not always feel comfortable with this provision of primary law and sometimes they happen to cite it with some inaccuracy. Suffice it to look at the EU regulation on personal data protection (GDPR), which entered into force in May 2018. ${ }^{7}$ This lack of comfort indicates that in the EU institutions there exists a desire, not quite articulated, to have competence also in the religious field. However, this is not just idle desire.

So how is EU policy and law regarding religion actually formulated? Certainly, one can speak here of a sui generis policy on religion, understood and implemented entirely differently than at the level of the nation-state. In view of the lack of EU competence in the religious field, it would be interesting to track how EU institutions are making an increasing number of decisions that have a direct impact on the lives of churches and religious communities. In general, we can say that EU practice, not only in this area, most often involves "processing" issues that fall outside the Union's competence into issues falling within the competence of the EU institutions. For example, education is perceived as a service, an abortion pill as a manifestation of concern for the health of consumers, an in vitro procedure as an element of care for the quality of medical equipment, the issue of ritual slaughter of animals as an environmental protection problem, the issue of availability of kosher meat in shops as an issue of consumers' access to food information, and the issue of work-free Sunday as a transport organisation issue. It would be interesting to trace thoroughly the legal bases cited in EU acts in which the word religion or the Church appears, as well as in those that actually have a significant impact on the life of religious communities. Given the lack of competence, elements of policy on religion are often articulated in documents belonging to the so-called soft law, e.g. in declarations and resolutions of

6 There is a broad literature on the State-Church (religion) relations, especially in the Western hemisphere (e.g., Ferari 2015; Fox 2015; Motzkin and Fischer 2008; Robbers 1996). There is no need to discuss it here as it is part of the common knowledge. This knowledge, especially regarding legal regulations, is needed to be able to conduct research on religion and the EU, but on the one hand-let us repeat-law and politics are not identical, on the other hand, the EU is not a state, which is of fundamental importance to this research.

7 The GDPR in Recital 165 apparently quotes Article 17 of the TFEU, but in fact makes its narrower interpretation, limiting the inviolability of the status of churches only to what is guaranteed in the national constitution: "This Regulation respects and does not prejudice the status under existing constitutional law of churches and religious associations or communities in the Member States, as recognised in Article 17 TFEU." 
the European Parliament. The mechanism for transforming issues not covered by EU competences into issues falling under these competences has been described in detail in the context of bioethical issues, as included in An Overview Report on Bioethics in the European Union (COMECE 2009), prepared by the COMECE Secretariat. Simply put, lack of competence is not an insurmountable barrier when it comes to the ability of the European Commission to conduct policy and make decisions. The effect of this approach to policy on religion is something that could be called the body of EU law on religion in statu nascendi with quite specific content, because the Union often regulates those aspects of the life of religious communities that, from the point of view of the nation-state, are not associated with religion at all. The method of regulating these issues is also specific, as it is most often an indirect action, e.g. officially the labelling of goods is addressed, but the result of the solutions taken may be depriving Judaism and Islam followers of access to food that meets the requirements imposed by their religion. Another example can be the dispute about non-discrimination in the labour market, which could have resulted in an EU order to ordain women as priests in the Catholic Church. The most frequently cited counterargument to accusations of non-compliance by the EU institutions with the principle of non-interference in religious matters is that this is not about intervening in the lives of churches and religious communities as religious entities, but interventions only to the extent that their activities fall under EU competence (Puza 2012, p. 53). Admittedly, this body of EU law on religion is just being created, but undoubtedly, in recent years the network of EU law, which determines some aspects of the life of religious communities, is definitely thickening.

It is also characteristic that the EU generally is rather generous regarding financial support for churches and religious associations (e.g., Caritas, Diakonia). These are primarily earmarked for the conservation and restoration of monuments, charitable activities, the integration of immigrants, etc. Behind the scenes in the EC, however, one can hear the advice to prepare applications in such a way that they are not associated with religion. It seems that this type of generosity might result from both realism and the desire to ensure the goodwill on the part of churches.

\section{EU Primary Law}

Although, as has been said, the law is not the same thing as policy, we can give substance to begin our reflection by showing the elements of policy on religion, which emerged during the discussion of EU law. Let us begin with EU primary law. Firstly, the disputes should be mentioned over the attempt to include in the preamble of the EU treaty a reference to Christian inspiration in the history of Europe: first in connection with the establishment of the Charter of Fundamental Rights, and then the Constitutional Treaty (later: the Lisbon Treaty) ${ }^{8}$. Both debates showed that, among member states, there is a deep division regarding attitude towards Christianity and diversity of views with regard to the understanding of the principle of state's neutrality vis-à-vis religion. It should be noted that the subject of the dispute was not an intention to make the EU a religious organization, but only the inclusion in the preamble of the aforementioned documents of reference to the Christian cultural heritage, which was a historical, cultural, and sociological information/declaration. During the debates, it was not proposed to use the formula invocatio Dei, but only-in the maximalist versions-nominatio Dei, and in the minimalist versions the word "Christianity" itself. In both cases, it turned out to be impossible due to opposition from Belgium and France. The representative of the latter country made

8 John Paul II personally insisted on including a reference to God or Christianity in both documents. At the moment when this postulate was disregarded, he did not hide his disappointment. "The European Union's effort to formulate a 'Charter of Fundamental Rights' is an attempt at a new synthesis, at the beginning of the new millennium, of the basic values that must guide the coexistence of European peoples. The Church has followed the drafting of this document with keen attention. In this regard, I cannot conceal my disappointment that in the Charter's text there is not a single reference to God. Yet in God lies the supreme source of the human person's dignity and his fundamental rights. It cannot be forgotten that it was the denial of God and his commandments which led in the last century to the tyranny of idols. A race, a class, the state, the nation, and the party were glorified instead of the true and living God. In the light of the misfortunes that overtook the 20th century we can understand: the rights of God and man stand or fall together." (John Paul II 2000). 
use of the argument that such a reference would be inconsistent with the constitutional tradition of France and the principle of secularism (laicité) contained in it ${ }^{9}$. This dispute shows that one "important" member state is able to block the will expressed by many or even the majority of member states and significantly influence the legal solutions adopted in this field. We witnessed a similar situation in the context of the dispute over the so-called Amsterdam Declaration. In each of the three cases cited, a compromise was finally reached, although the path that led to reaching the final solution was different. In the case of the Amsterdam Declaration, it was finally adopted thanks to the persistence of Germany, and more specifically, Chancellor Helmut Kohl, but at the same time lowering the rank of the document from the proposed protocol to the level of the declaration. In the case of the Charter of Fundamental Rights, it was agreed that there would be a discrepancy between the official French and German versions of its text, responsibility for which would be placed on EU translators. The French text thus recalls le patrimoine spirituel et moral, and the German text recalls das geistig-religiösen und sittlichen Erbe. The English text is consistent with the French. Officially, both expressions are synonymous. In the case of the preamble to the Treaty on European Union, instead of recalling the Christian roots of Europe, we have a reference to the "cultural, religious and humanist heritage of Europe". At the same time, EU politicians in their talks often used the argument that "religious" in Europe means "Christian", which is obvious to everyone and therefore the expressions are synonymous. If we ask where the reluctance to use the word "Christianity" came from, apart from the possible ideological hostility of some politicians, one can cite an argument closely related to the sense of invocatio or nominatio Dei in constitutional documents, or rather to avoidance of this reference. It can be seen either as an attempt to distance oneself from the European tradition of separation of state and religion (a shift from the model of friendly separation to the French model of hostile separation) or as the intention to part with invoking religious arguments to justify the inviolability of human rights. If the latter argument were true, it would be equivalent to striving to bring about an anthropological change in EU policy and, consequently, a reinterpretation of the entire doctrine of human rights. ${ }^{10}$

The correctness of the above assumption seems to be proved by the change introduced by the EU Charter of Fundamental Rights in the way of defining the institution of marriage. Article 9 of the Charter reads: "The right to marry and the right to found a family shall be guaranteed in accordance with the national laws governing the exercise of these rights." The meaning of this sentence can be read only in the context of the change it introduces in relation to Article 12 of the European Convention on Human Rights-ECHR, which expressly states that such a right applies to a man and woman of marriageable age. The resignation from explicitly mentioning a man and a woman is explained in the Explanations to the CFR by the desire to "modernize" the definition of marriage. ${ }^{11}$ We often witness a similar approach with regard to other human rights at the level of secondary law.

9 During a lecture in Warsaw as part of the conference “John Paul II: Foundations of Democracy" on 31 May 2019, Joseph Weiler mentioned his conversation with Valéry Giscard d'Estaing on the reference to Christianity in the preamble to the Constitutional Treaty. D'Estaing made his case that, although he wanted to introduce Christianity into the Treaty, there was no consensus. Weiler was going to say, "So you had to put this into a draft you wrote yourself, and then there would be no consensus to get it out." The former French president was supposed to reply: "Monsieur, vous êtes méchant."

10 In 1947, Pius XII wrote to American President Harry Truman explaining that excluding God from the Universal Declaration of Human Rights would mean recognizing that man is the author of human rights, which would ultimately reduce him to the status of a slave in the hands of those who could manipulate the meanings of words used in it: "The foundations of peace] can be secure only if they rest on bed-rock faith in the one, true God, the Creator of all men. It was He who of necessity assigned man's purpose in life; it is from Him, with consequent necessity, that man derives personal, imprescriptible rights to pursue that purpose and to be unhindered in the attainment of it. Civil society is also of divine origin and indicated by nature itself; but it is subsequent to man and meant to be a means to defend him and to help him in the legitimate exercise of his God given rights. Once the State, to the exclusion of God, makes itself the source of the rights of the human person, man is forth-with reduced to the condition of a slave, of a mere civic commodity to be exploited for the selfish aims of a group that happens to have power. The order of God is overturned; and history surely makes it clear to those who wish to read, that the inevitable result is the subversion of order between peoples, is war" (Pius XII 1947).

11 "Explanation on Article 9-Right to marry and right to found a family-This Article is based on Article 12 of the ECHR, which reads as follows: 'Men and women of marriageable age have the right to marry and to found a family according to the national laws governing the exercising of this right.' The wording of the Article has been modernised to cover cases in which national legislation recognises arrangements other than marriage for founding a family. This Article neither prohibits nor imposes 
The third area of primary law, significant from this point of view, is the description of the right to religious freedom in Article 10 of the Charter of Fundamental Rights. It must be admitted that in this case there were no modernization attempts. The description contained in paragraph 1 is "classic" and includes all aspects of the right to religious freedom, with the exception of its institutional dimension. "Everyone has the right to freedom of thought, conscience and religion. This right includes freedom to change religion or belief and freedom, either alone or in community with others and in public or in private, to manifest religion or belief, in worship, teaching, practice and observance." In the explanations to the Charter, it was stated that this right has the same content and scope as Article 9 of the European Convention, also when it comes to the possibility of limiting this right in accordance with Article 9 (2) of the ECHR. In this context, Article 10 (2) of the Charter additionally mentions the right to conscientious objection. "The right to conscientious objection is recognised, in accordance with the national laws governing the exercise of this right."

The institutional dimension of religious freedom is referred to in the already mentioned Article 17 of the Treaty on the Functioning of the European Union, where in paragraph 1 we read: "The Union respects and does not prejudice the status under national law of churches and religious associations or communities in the Member States." This provision is seemingly conservative. Therefore, the Union does not intend to change anything when it comes to the functioning of churches in the member states, and therefore-one would like to say-it does not conduct any policy on religion. However, Article 17 is not limited to the first paragraph, but also contains two more. In paragraph 2-a complete novelty- the Treaty repeats almost literally the same formula but with regard to philosophical and non-confessional organizations. Placing them in the same article, and not, for example, in Article 15 concerning civil society or in a separate article designated only to them means that from the point of view of EU law, they are entities of the same or very similar type as churches and religious communities. It is a political decision whereby the Union grants philosophical and non-confessional associations, with a total number of around 100-200 thousand members in Europe, the same status as churches and religious communities representing around 85 per cent of EU citizens. This is of particular significance in the context of paragraph 3 of the same article, in which we read: "Recognising their identity and their specific contribution, the Union shall maintain an open, transparent and regular dialogue with these churches and organisations." 12 This paragraph applies to the same extent to entities falling under paragraphs 1 and 2.

Strictly political elements also appear in the way this dialogue is to be organized. The first question is, are these organizations and churches to conduct this dialogue together, i.e., in the framework of the same meetings, or separately? Secondly, in the latter case, how numerous should be the representations of the respective entities? Thirdly, what is the practical implementation of the postulate of neutrality vis-à-vis religion on the part of EU institutions? Regarding the first question, attention should be paid to a completely different dynamic of the debate when, on the one side, we have the representatives of EU institutions, and on the other, representatives of churches and religious communities, as the perception of political reality by organizations of a religious nature is, despite all the differences, quite similar. The dynamics of meetings is completely different, when representatives of churches and non-confessional associations (which, in practice, denotes atheistic and masonic organizations) sit together in front of EU officials. In the latter case, the demands made by the participants usually cancel each other out. In the first case, it is possible to reach some common conclusions; in the second, we have a zero-sum debate. Regarding the second question, it should be stated that it is possible to organize such a meeting according to the principle of geometric (proportionate) equality (the number of members of delegations of individual entities is proportional to the number of their members in the EU). However, it should be taken into account that in such situation we would

the granting of the status of marriage to unions between people of the same sex. This right is thus similar to that afforded by the ECHR, but its scope may be wider when national legislation so provides." (Official Journal of the European Union 2007).

12 More on the dialogue as such: (Mazurkiewicz 2011, pp. 97-110). 
have to deal with Catholic domination, as approximately $50 \%$ of EU citizens belong to this Church. The use of the principle of degressive proportionality could be conceivable, as in the case of national representations in the European Parliament. Although there exist practical ways of addressing the issue of fair representation of the different entities, in practice they are never used, which in itself is a political decision. For example, one of the meetings of the dialogue in the European Parliament in 2012 was attended by 15 representatives from various entities falling under Article 17. Seven were religious in nature, seven were secular, and one could be placed somewhere in between. This means that a small atheistic organization or Masonic lodge had as many representatives (one per each entity represented) as the Catholic or Protestant Church and had the same length of time allotted in discussion. Perhaps this would not pose a major problem if it were not for the practical answer to the third question regarding neutrality, for it is sometimes understood in such a way that equal weight is attached to each statement. Therefore, we are dealing here with a declared weighting of votes, but a very specific one, à rebours, as if to assume that the largest representation in parliament is granted to the one who obtains the fewest votes in the parliamentary elections. This leads to a drastic overrepresentation of marginal voices. As a result, the initiative to define the outcome of such organized consultations falls upon the given EU institution. Looking at this practice from the point of view of EU policy on religion, one must say that the EU consciously promotes the secular position represented mainly by small entities. ${ }^{13}$ This is accompanied by a debate held mainly in the European Parliament, in which there also appears a proposal by secularists that the churches should be reduced to the level of large non-governmental organizations, i.e., for example without the right to conclude concordats, which—in such a case—-the Union would treat as null and void. One of the tools of conducting such a policy is the European Parliament Platform for Secularism in Politics (https://www.secularism.org.uk/defend-equality-laws/european-parliament-platform-for.html), established in 2009. The fact that its representatives are involved in each decision-making process on matters relating to religious freedom shows the idea that potential enemies of religious freedom must also co-decide about religious freedom in the EU. It must be said that this procedure is practiced not only in the field of policy on religion, but also, for example, in the area of non-discrimination policy, as discussed below. ${ }^{14}$

\section{EU Secondary Law}

Despite the lack of competence to regulate the status of churches and religious communities, EU law and policies significantly affect this status, although, as already mentioned, it happens differently than in the case of the influence of domestic law. Regarding secondary law, terms such as religion or churches appear mainly in the lists of, for example, various forms of diversity or bases of non-discrimination. We are dealing with similar lists also in primary law. Often in acts of secondary law we deal with exclusion clauses, and therefore with the exclusion or possibility of excluding religious entities from the obligation to apply a directive or regulation, most often only referring to some of their specific provisions. One of the recent regulations introducing such a clause of significant practical importance is the aforementioned regulation on the protection of personal data, which provides for the possibility of excluding churches from its jurisdiction, provided that on the date of the GDPR's entry into force a given church had an autonomous data protection system and adjusted its standards to those contained in the regulation.

Issues important from the point of view of religious communities, and which may have a significant impact on their functioning, appear in various, sometimes the most surprising documents, e.g., on transport or child labour (the only mention of Sunday as a special day of the week in EU law),

13 Another manifestation of the EU's concept of neutrality is the original ban on the inclusion of religious symbols on euro coins and banknotes, overcome for the first time by the Slovak government.

14 The Religare research project sponsored by the European Commission is constructed in a similar way (Religare-Eu Project 2014). 
animal welfare (regulations regarding ritual slaughter), prohibition of discrimination (e.g., regarding the possibility of preventing women (priesthood of women) or people of different religious background (Catechesis) from entering certain professions, or selecting students of religious schools according to religious criteria, etc.). On the other hand, churches are keenly interested in the ethical side of many EU decisions, regarding, e.g., funding research on human embryonic stem cells (which involves the destruction of human embryos), transplantation, or development aid (under which the EU funds abortion, contraception, and sterilization in developing countries). Sometimes, a risk appears that the decisions made will directly violate the right of religious communities to spread freely their moral teachings (e.g., the prohibition of homophobia is sometimes understood as a prohibition of moral condemnation of homosexual acts).

The list of this type of potentially conflicting issues increases with the expansion of the scope of competences of EU institutions. The essence of the problem is a phenomenon that can be called a conflict of two anthropologies. National diversity, with its associated different cultural traditions; the quantitative advantage of the "old Union" over the "new" in EU institutions; the left-wing's overrepresentation among the EU elites, with their simultaneous disconnection from their own societies, make the worldview dispute in the EU institutions (in which on the one hand, we have a Christian position, and on the other, a left-materialist position; on one side, a vision of constrained anthropology - through the awareness of being a creature that must take into account the will of the Creator and through the awareness of the existence in the world of consequences of original sin-and on the other, unconstrained anthropology, where a human being is perceived as a random fruit of the blind forces of evolution, and at a next stage he may try to direct this process, transforming his nature without any predetermined constraints) take on an intensity unheard of elsewhere in Europe. This phenomenon was well described by Michał Gierycz in the book entitled European Dispute over Man (Gierycz 2017) ${ }^{15}$.

\section{Migration Policy and Accession Policy}

The accession policy and migration policy are special tools of policy on religion. They are, in a sense, macro-tools. Given that for some time (especially since 2014), the flow of immigrants reaching Europe has been strongly dominated by followers of one non-European religion, decisions regarding the preferred countries of origin from which EU Member States accept immigrants and the number of immigrants admitted have, in the long term, a significant impact on the religious demographic structure of the Old Continent ${ }^{16}$. It should be noted that, generally, the fertility rate is also religiously differentiated. One can therefore say that, to a large extent, it is politicians who decide the future proportions between the various faiths and religions in Europe. It is also politicians who decide whether the European landscape will be dominated by the spiers of Gothic cathedrals or, rather, by the spikes of minarets. ${ }^{17}$

Sometimes, the opinion is expressed that the decisions made in this area are largely motivated by ideological reasons. It is about the ideology of multiculturalism, which—as Samuel Huntington pointed

15 The distinction between constrained and unconstrained anthropology is taken from the book by Thomas Sowell (2007). It was discussed by me in the work Le différend de deux anthropologies dans la politique européenne (Mazurkiewicz 2017b) and analysed in detail on the base of specific EU directives and regulations by Michał Gierycz (2017).

16 In its forecasts, the Pew Research Center points to the close relationship between the religious structure of European societies and the migration policies of European governments. For example: in 2050, Muslims will represent 7.4\% of the European population with zero migration, $11.2 \%$ with medium migration and $14 \%$ with high migration. This study contains many other interesting data on this subject (Pew Research Center 2017a).

17 "The idea of a clash between Islam and "the West" — a word in which everything is put together and confused-has misled our policies and our narratives. Islam holds a place in our Western societies. Islam belongs in Europe. It holds a place in Europe's history, in our culture, in our food and-what matters most-in Europe's present and future. (... ) Some people are now trying to convince us that a Muslim cannot be a good European citizen, that more Muslims in Europe will be the end of Europe. These people are not just mistaken about Muslims: these people are mistaken about Europe, they have no clue what Europe and the European identity are." (Mogherini 2015). 
out-is essentially anti-European, as its aim is to oppose the homogeneity of European societies. It should be emphasized, however, that if Europe is homogeneous in any respect, then only in the sense that it is/was Christian (Huntington 2005, pp. 173-80; Bock-Côté 2019; Mazurkiewicz 2020). Thus, an attempt to break down this social homogeneity and replace it with heterogeneous societies means nothing less than the desire to replace societies dominated by Christian culture with multicultural societies in the name of "cultural enrichment." A symbolic gesture was the removal from the three million copies 2010/2011 calendar, intended for school students across Europe, of Christian holidays, including Christmas and Easter, and replacing them with holidays of other religions, including those with marginal representation in the EU (Chayet 2011). The expected results of the ideological policy of multiculturalism seem to find good reflection in the forecasts presented by the Pew Research Center, showing the dynamics of religious changes in individual EU countries until 2060 (Pew Research Center 2017b).

The change in the religious demography of Europe, which may take place in the next 40 years due to the migration policy, can come about in a much shorter time as a result of decisions on future accessions to the EU. A decision to admit to the Union, at one fell swoop, either 83 million Muslims or 43 million Christians, would fundamentally change the religious structure of the EU community for many years to come. This is, of course, about a possible EU accession of Turkey or Ukraine. It is difficult not to take into account certain gestures of hostility towards Europe made by the Turkish government. I am thinking of both the use of "migrant blackmail" and the transformation of Hagia Sophia into a mosque, which is an event with a very strong symbolic meaning (Schinas 2020; Orthodox Times 2020). I am not advocating here to recognize that Christians are better suited to be EU citizens than Muslims are, but only to note that a political decision to admit this or that country has a significant impact also on the religious structure of the EU population.

The EU's policy on religion will probably also change under the influence of smaller scale decisions. So far, the Muslim community is represented in the EU through minorities in individual member states, and politicians who profess Islam join EU institutions on behalf of the same parties as their non-Muslim colleagues. The accession to the Union of countries such as Albania or Bosnia and Herzegovina would result in Muslims also gaining an independent vote in the EU Council, and over time, perhaps, would also lead to the appearance of an Islamic party in the European Parliament. Probably, this independent voice would not determine the overall shape of EU policies, but even in the case of countries with relatively small populations, it would certainly have an impact on these decisions and would force the integration of the Islamic point of view into decisions taken. However, raising the rank of the opinion of the Muslim community from being represented by individual persons (MPs, politicians representing a member state, EU officials who are followers of Islam), or by a Muslim delegation participating in meetings under Article 17, to the voting level of a member state would represent a qualitative change.

\section{EU's External Policy}

Issues related to religion also arise in the field of EU's external policy. All the EU institutions actually participate in shaping it, and the intergovernmental element characteristic of the EU Council is relatively strong. This fact, as well as the fact that the policy is addressed to third countries, means that the approach to religious freedom within its framework is less saturated with Brussels jargon and EU correctness, and more similar to the concept present in international law documents related to human rights.

Calls for respect of freedom of religion appear frequently in declarations and resolutions of the European Parliament, most often in the context of condemning of specific crimes committed in a third country. We sometimes see condemnation of such acts in the conclusions of the meeting of the Council of Ministers of Foreign Affairs, much less often in the speeches of the High Representative for external action. Characteristic for these appeals is their ambiguity, which is a consequence of a specifically understood political correctness. Firstly, for a long time, mentioning the religious affiliation of victims of condemned terrorist attacks, if they were Christians, was avoided with a shudder. Later it 
became customary to use a general formula for victims of persecution belonging to different religions, "Christians included". This was driven by the concern to avoid the slightest appearance that the Union prefers Christianity or somehow identifies with it, or that it associates specific acts of terrorism with any particular religion. Secondly, condemning the perpetrators of a particular attack was eschewed, always including in the given document a list of acts of terror that took place over a long period, so as not to stigmatize any single state. As a result, the published statements showed that we dealt with violations of religious freedom everywhere, and that the victims were representatives of all religions, Christians included. ${ }^{18}$

A positive gesture was the Foreign Affairs Council's adoption, in 2013, of the EU guidelines on the promotion and protection of freedom of religion or belief, which were to guide EU ambassadors regarding the monitoring of the state of religious freedom in third countries (Council of the European Union 2013). In practice, however, the guidelines did not play a significant role until the appointment in 2016 of the Special Envoy for promotion of freedom of religion or belief outside the EU in the person of Ján Figel', which "activated" this document. It draws attention that the EU Special Envoy, whose mission ended in 2019 with the election of the new European Commission, was not anchored in the EEAS, but inside the European Commission as a special advisor to the Commissioner for International Cooperation and Development. ${ }^{19}$ This significantly weakened the Special Envoy's ability to influence the EU's external policy, as compared to his potential placement within the EEAS. In this situation, one of the main potential tools to influence the state of religious freedom in third countries are possible conditionality clauses in trade agreements, making the level of economic relations dependent on the state of religious freedom in a given country.

We can say that in the framework of EU's external policy one can note a desire to create the appearance of genuine commitment of EU institutions to defend religious freedom, including Christians. It seems that this is mainly because of the public opinion within the Union itself, which is to a large extent shaped by Christians.

\section{Jurisprudence of the ECtHR and the ECJ}

In general, at least two more factors are mentioned that link the process of European integration with changes in the status of churches and religious communities. One is the, let us call it spontaneous, process of harmonization of laws and the so-called good practice within the Union itself. Over the last few decades, the Member States have gradually become more similar to one another when it comes to their internal regulations concerning the relations between the state and the church/religious communities. Extreme solutions, e.g. in the form of a confessional state, have either been abandoned (Sweden in 2000) or have lost much of their "severity" (Finland, Greece).

The second factor is the jurisprudence of European courts. In the field of religious freedom, the vast majority of jurisprudence is "produced" by the European Court of Human Rights-ECtHR, which is not an EU institution but whose jurisdiction binds all EU member states. ${ }^{20}$ However, sometimes the European Court of Justice-ECJ also gives rulings on matters directly related to religion. I am

18 Franco Frattini, Italian foreign minister, who personally sought to condemn attacks on Christians by the Council of the European Union, interviewed by "Avvenire" on 3 March 2011, following the assassination of Shahbaz Bhatti, Catholic Minority Minister in the Pakistani government, said in undiplomatic terms: "Now the cowards of that Europe which flees from the condemnation of religious fundamentalism will shed their crocodile tears, allies of those cowards in Pakistan who know only the blood of attacks [...] I am thinking of those in Europe who are very attentive to the 'politically correct', to the point of never using, in official documents, the words 'persecuted Christians'. I see this as o form of political cowardice which today, in the face of a new martyr, is even more scandalous." (Geninazzi 2011).

19 Ján Figel's mandate ended with the election of the new European Commission. Maragaritis Schinas, Vice-President of the European Commission announced on 8 July 2020 that the Commission would soon renew his mandate. In August 2020, however, it was still unclear whether it was about renewing Figel's mandate or only about renewing the office and appointing another person (Juncker 2016; Gagliarducci 2020; Respinti 2020).

20 In recent years, the most prominent was the judgment in the case of Lautsi v Italy (European Court of Human Rights 2011). The activity of the ECtHR in the field of religious freedom can be traced on the basis of the Council of Europe Research Division Report (Council of Europe. Research Division 2013). 
thinking, for example, of the ECJ decision in case C-84/94, United Kingdom v Council, which abolished the legal protection in the EU of Sunday in the Working Time Directive, stating that the Council did not provide justification confirming the link between Sunday rest and the health and safety of workers (European Court of Justice 1996). Other examples may include the ECJ rulings in cases C-157/15, G4SSecure Solutions (European Court of Justice 2017a) and C-188/15, Bougnaoui and ADDH (European Court of Justice 2017b) relating directly to the possibility of wearing visible signs of religious beliefs at the workplace. Undoubtedly, the number of judgments issued in matters relating to religion is much greater in the case of the ECtHR than in the case of the ECJ. However, the prospect of EU's accession to the ECHR may make this last remark redundant.

One of the most symptomatic expressions of the above-mentioned a conflict of two (Christian and materialistic) anthropologies at the European Court of Justice level is the case of Brïstle vs. Greenpeace (Case C-34/10) and the controversy that arose as a consequence of the judgment. It is worth devoting a little more space to its analysis because, as mentioned, potential restrictions on religious freedom in the EU generally do not take place directly, but mainly due to divergent positions on fundamental ethical issues and political and legal pressure to persuade churches and religious associations to "correct" proclaimed ethical beliefs, which usually form integral part of their doctrine. As we read in the ECJ judgment: "Mr Brüstle is the holder of a German patent, filed on 19 December 1997, which concerns isolated and purified neural precursor cells, processes for their production from embryonic stem cells and the use of neural precursor cells for the treatment of neural defects" (European Court of Justice 2011, 15). On application by Greenpeace, the Bundespatentgericht (Federal Patent Court) ruled that the patent obtained by Olivier Brüstle was invalid "so far as it covers precursor cells obtained from human embryonic stem cells and processes for the production of those precursor cells" (ibid. 19). Brüstle appealed against that judgment to the Bundesgerichtshof (Federal Court of Justice) which decided to refer three extensive questions to the European Court of Justice for a preliminary ruling. The first one, concerning the definition of a human embryo used in the Directive 98/44/EC of the European Parliament and of the Council of 6 July 1998 on the legal protection of biotechnological inventions, was the most important. Other two, concerning the meaning of the expression "uses of human embryos for industrial or commercial purposes" and the patenting of technical teaching related to the use of human embryos, were of an auxiliary nature. It seems, they were added to unequivocally suggest the ECJ to narrow down the interpretation of the exclusions provided for in the Directive, to make it more "friendly" to the development of inventions based on the use and destruction of embryos (Maśnicki 2013). The first question was as follows: "What is meant by the term "human embryos" in Article 6(2)(c) of [the Directive]? (a) Does it include all stages of the development of human life, beginning with the fertilisation of the ovum, or must further requirements, such as the attainment of a certain stage of development, be satisfied? (b) Are the following organisms also included: unfertilised human ova into which a cell nucleus from a mature human cell has been transplanted; unfertilised human ova whose division and further development have been stimulated by parthenogenesis? (c) Are stem cells obtained from human embryos at the blastocyst stage also included?" (European Court of Justice 2011, 23).

The opinion of advocate general delivered on 10 March 2011 was crucial to the case. He proposed a legal definition of a human embryo which was then integrated into the final decision of the Court (Bot 2011). In the Judgment ECJ states that, on the one hand, "the definition of human embryo is a very sensitive social issue in many Member States, marked by their multiple traditions and value systems" (30), on the other hand, that there must be a common definition of the human embryo to avoid at least chaos link with a forum searching for the patenting. "The lack of a uniform definition of the concept of human embryo would create a risk of the authors of certain biotechnological inventions being tempted to seek their patentability in the Member States which have the narrowest concept of human embryo and are accordingly the most liberal as regards possible patentability, because those inventions would not be patentable in the other Member States" (28). In this situation, the ECJ decided to avoid questions of medical or ethical nature, restricting itself to a legal interpretation of the relevant 
provisions of the Directive. Frist of all, the Directive was issued to protect dignity of the person and his fundamental rights. In particular, "patent law must be applied so as to respect the fundamental principles safeguarding the dignity and integrity of the person" (32). This leaded the Court to the conclusion, which is opposite to the intention of the German Constitutional Court: "It follows that the concept of 'human embryo' within the meaning of Article 6(2)(c) of the Directive must be understood in a wide sense" (34). Finally, the Court shared the legal definition of the human embryo proposed by the Advocate General. In the conclusions we find negative answers on three questions posed by the German Constitutional Court:

1. Article 6(2)(c) of Directive 98/44/EC of the European Parliament and of the Council of 6 July 1998 on the legal protection of biotechnological inventions must be interpreted as meaning that:

- any human ovum after fertilisation, any non-fertilised human ovum into which the cell nucleus from a mature human cell has been transplanted, and any non-fertilised human ovum whose division and further development have been stimulated by parthenogenesis constitute a 'human embryo';

- it is for the referring court to ascertain, in the light of scientific developments, whether a stem cell obtained from a human embryo at the blastocyst stage constitutes a 'human embryo' within the meaning of Article 6(2)(c) of Directive 98/44.

2. The exclusion from patentability concerning the use of human embryos for industrial or commercial purposes set out in Article 6(2)(c) of Directive 98/44 also covers the use of human embryos for purposes of scientific research, only use for therapeutic or diagnostic purposes which is applied to the human embryo and is useful to it being patentable.

3. Article 6(2)(c) of Directive 98/44 excludes an invention from patentability where the technical teaching which is the subject-matter of the patent application requires the prior destruction of human embryos or their use as base material, whatever the stage at which that takes place and even if the description of the technical teaching claimed does not refer to the use of human embryos" (53).

In its judgment, the ECJ adopted the legal definition of the human embryo and recognized the moment of the creation of the human embryo as the beginning of the development of the human person. This way the EU established a legal definition of the human embryo which is totally in line with the European and Christian tradition of understanding the human person. Two people played a very important role in this procedure: Yves Bot, advocate general, and Marek Safjan, rapporteur.

The elaboration of a definition of the human embryo by ECJ has placed at the heart of EU policy the question of whether all activities related to the life and dignity of human embryos, carried out under different competences, are consistent with each other. The organisers of European Citizens Initiative "One of Us" claimed that to grant that consistency the EU should prohibit and end funding of activities that imply the destruction of human embryos, in particular in the areas of research, development and public health. In the "One of Us" proposal, one read: "i) There shall be excluded any political support and a fortiori the funding from the Union of actions that assume or carry out the destruction of human embryos; 1) The objective of the citizens' initiative is to get the commitment of the Union in all these areas not to allow and not to fund actions that assume or carry out the destruction of human embryos and to provide suitable control tools for the use of allocated funds in order to ensure that they are never used to destroy human life" (European Citizens' Initiative "One of Us" 2012).

Despite the fact that the Initiative gained the support of almost two million EU citizens from different countries (against one million required by law), the European Commission decided not to pursue it any further. Mainly because the decision-making procedures applied by the European Commission in the areas covered by the Initiative meet "the highest ethical standards"; "the highest" and therefore impossible to be improved by ordinary citizens. "EU primary legislation explicitly enshrines human dignity, the right to life, and the right to the integrity of the person. The EU Financial Regulation 
states that all EU expenditure should comply with EU primary legislation. Therefore, the Commission does not see a need to propose changes to the Financial Regulation" (European Commission 2014).

This way of treating the will expressed by EU citizens clearly shows what was reflected in the discussions on the Lisbon Treaty: the "democratic deficit" in the EU does not only result from the objective difficulties of empowering EU citizens, but above all from the fear of EU bureaucrats concerning what citizens can request of them. In other words, the instrument of the citizens' initiative is structured in such a way that the Commission takes a specific legislative initiative only when the will expressed by the citizens agrees with the will of the bureaucrats, and it does nothing if the citizens dare to disagree with their elites on a matter. The only reason for the discrepancy may be a lack of competence or "lower ethical standards" represented by ordinary citizens.

On 25 July 2014, the European Citizens' Initiative "One of Us" filed a complaint with the Court in Luxembourg against the European Commission, the Council of the European Union and the European Parliament, requesting annulment of the decision of the European Commission not to forward the initiative to the European Parliament and the Council of the European Union (European Court of Justice 2014a). The Second Chamber, dismissing the complaint on 23 April 2018, found convincing arguments of the European Commission justifying the necessity to finance "safe abortion" in developing countries (European Court of Justice 2018). Which, from the point of view of common sense, seems to reinforce the anthropological and ethical inconsistency in the EU policy. In the meantime, between 2012 and 2018, the Court of Justice delivered its judgment in Case C-364/13 International Stem Cell Corporation vs. Comptroller General of Patents, Designs and Trade Marks, on whether methods of producing pluripotent human stem cell lines from parthenogenetically-activated oocytes and stem cell lines produced according to the claimed methods can be patented. In the judgment ECJ declared that "an unfertilised human ovum whose division and further development have been stimulated by parthenogenesis does not constitute a 'human embryo', within the meaning of that provision, if, in the light of current scientific knowledge, it does not, in itself, have the inherent capacity of developing into a human being, this being a matter for the national court to determine" (39) (European Court of Justice 2014b). In both cases, on One of Us and on International Stem Cell Corporation, it can be seen that the Court was trying to narrow down the legal definition of an embryo developed in Brüstle and limit the consequences of its application to the European law. This clearly shows how it seems that the Tribunal is trying to reconcile both contradictory anthropologies in its jurisprudence, by favoring, on in essence the same issue, sometimes the side of one of them, sometimes more of the other. Nevertheless, the ethical sensitivity of the Tribunal in this respect was undoubtedly greater than that of other EU institutions.

\section{Res novae in the Field of Religion and EU Policy}

The density of mutual relations between the EU institutions and churches and religious associations is constantly increasing, but at the same time, there is a growing tendency in EU policy to change these religions from within through their own actions. To illustrate this issue, it is sufficient to cite the Regulation (EU) 2016/679 of the European Parliament and of the Council of 27 April 2016 on the protection of natural persons with regard to the processing of personal data and on the free movement of such data (Official Journal of the European Union 2016). Although Article 91 (1) leaves churches and religious associations the right to retain an autonomous system of personal data protection, it is only at the cost of transferring to the canon law system the model of data protection enshrined in EU law. Politicians, therefore, set the standards for the protection of these data in the churches. An analogy can also be seen in the ongoing debates on non-discrimination and sexual abuse. Under the influence of political and media pressure, churches often take over from the secular debate not only the sensitivity (which is good in itself) but also the terminology and standards for the protection of persons, in particular minors. It is not about condemning such a practice, but about the need to be aware of the very fact of its existence.

A small thought experiment can be helpful in understanding the essence of another innovative element present in the EU's policy towards religion. Imagine that we take up a photo taken in Germany 
in May 2018. It shows the interior of a Roman basilica from the time of Constantine, currently used by the Protestant Church. In the center of the photography, there is an altar with the slogan: "1818-2018. Karl Marx-Trier" ${ }^{21}$ On the other side of the altar, in the place where normally Pastor is holding the liturgy, we see Jean-Claude Juncker, President of the European Commission, addressing the audience. This raises a few naive questions: Why did this meeting take place in the church? Are we dealing with a service or is it a political rally? Why is this "pastor", a member of Christian democracy, promoting in the church "the creator of international communism"? Has the Church changed its attitude towards atheist Marxism and no longer treats it as a synonym of godlessness? Is the European People's Party the successor of the Communist International and the European Union the heir of the Soviet Union? These questions may seem frivolous, but the photograph undoubtedly shows an encounter of two worlds: religion and politics, with the former giving its space as the host, and the latter taking over the teaching mission. The ceremony in Trier ended with the unveiling of a few meters' high statue of the "great philosopher", gifted by the People's Republic of China.

Another example of politicians' new approach to religion was the behavior of many national governments in Europe in connection with the COVID 19 pandemic. Adopted procedures for imposing restrictions on churches and religious communities varied across Europe. In some of them, the state made its own decisions in this matter, in others, these decisions were post-factum authorized by the bishops, in others- they were the result of dialogue between the government and the episcopal conference. Nevertheless, almost always the restrictions imposed on the participation of the faithful in the services were more restrictive than, for example, related to the possibility of doing everyday shopping. In itself, this means that material needs were considered more important than spiritual one. In France, for example, the Council of State considered "a general and absolute prohibition [to organize religious ceremonies] disproportionate" and ordered its abolition. However, it happened only after two months of the restrictions (Sugy 2020). Interestingly, in the briefing published by the European Parliamentary Research Service on the restrictions imposed on EU citizens in connection with the pandemic, the topic of religion does not appear at all (European Parliamentary Research Service 2020).

\section{Risk of Resacralisation of Law and Policy}

After the terrorist attack at the Zaventem airport in 2016, there was a discussion in the Belgian press about possible tools for the effective integration of immigrants. One idea was to introduce a compulsory subject in Belgian schools, which was originally called les cours de rien, lessons about nothing. The originator of the idea assumed that the schools in Belgium (where lessons of Catholic, Protestant, Christian Orthodox, Islamic, and Judaic religions, as well as ethics lessons, are conducted) are not neutral enough, which is the cause of the emerging religious fundamentalism, hence the idea to introduce a new compulsory subject that would serve to educate children and adolescents within a worldview that goes beyond each of these particular points of view. Eventually, the subject was introduced to schools, albeit under a different name.

Looking at the EU's policy on religion, highlighting its unique character, it can be said that, despite the fact that schools for children of European officials conduct religion lessons, the vision of worldview neutrality comes quite close to the one espoused by the proponent of the idea of Belgian cours de rien. When making decisions, political realism requires the existence of religious communities to be taken into account as a social fact, and therefore to try to win their goodwill or at least cold indifference, but it seems to be accompanied by a hope that thanks to long-term policy, religions will change, somehow becoming similar to Belgian cours de rien. Churches and religious communities are

21 In his speech in honour of Karl Marx, Jean-Claude Juncker said: "Karl Marx was a philosopher, who thought into the future had creative aspirations. ( ... ) Today he stands for things, which he is not responsible for and which he didn't cause, because many of the things he wrote down were redrafted into the opposite. (...) He is the main founder of Marxism, the founder of Marxist political parties and the creator of international communism, and the greatest thinker of modern times" (Churm 2018); Full recording the President Juncker's speech: (Juncker 2018). 
therefore an important partner of EU consultations, but at the same time, by involving them in this process, efforts are made to neutralize their religious message. The aim is to create a religion consistent with EU standards, devoid of a critical edge vis-à-vis the political sphere, legitimizing, if only tacitly (qui tacit consentire videtur), above all, the process of European integration itself, but also the project of ideological reconstruction of European societies. Looking at EU policy on religion in statu nascendi, one may get the impression that it primarily expresses the need of EU leaders for a religion of political optimism that will nurture faith in earthly success, even if the political actions taken could seem utterly irrational. The European Union is trying to "domesticate" churches and religious associations, mute their tendency to political pessimism and criticism of political power, and "hollow out" religions from their theological core. The idea is to create a new political religion, built on the rubble of traditional beliefs, but without violent revolution, demolition of churches, and removal of hierarchs. All this should be done in an evolutionary manner, using the mechanism of co-opting religious elites into the EU establishment. We observe a similar process, albeit with the use of different instruments, at the level of nation states.

Two inevitable consequences of such a process are worth noting. The first is the emergence of a kind of "secular theocracy". ${ }^{22}$ If Christianity served as a natural barrier to the aspirations of secular power to over-accumulate sovereign powers, the "taming" and "domestication" of Christian churches results in the resacralisation of the secular power, which in fact takes over the leadership in both the temporal and spiritual spheres. Then the dual division of powers, characteristic of Europe, the feature of which was the coexistence of two competing centres of power in the same area and in relation to the same people (if they are believers); secular and spiritual, disappears from the scene of social life. This type of separation of powers protects against the possibility of emergence of absolute/total power to a much greater extent than Montesquieu's known and valued trias politica division of power. The former has a more primal character.

The second consequence is the observed process of resacralisation of the law. Jacek Salij OP notes that the abandonment of natural law as the foundation of social life as a result of legal positivism has led today to a kind of sacralization of statutory law (Salij 2018) thus a process opposite to the one mentioned by Benedict XVI in his speech to members of the German parliament. ${ }^{23}$ Attempts to legally redefine the institution of marriage and family are one of the manifestations of this phenomenon. The aforementioned resacralisation of the law results from the fact that the legislator-perhaps not fully consciously_arrogates to itself divine prerogatives. At the same time, depriving religion of a transcendent authority reminding the ruler that he is not God and that his powers of authority are limited by the mere fact of being a creature, leaves him without an intellectual and institutional barrier. Moreover, in the context of legal positivism, as a rule, the links between law and morality are loosened. Going beyond the paradigm of the Creator and creation, "objective and subjective reason ( ... ) rooted in the creative reason of God" (Benedict XVI 2011), and consequently causes the questioning of the very idea of human nature, and therefore also the common and unchanging moral norms common to

22 This term is used, for example, by Paul Edward Gottfried in the subordinate title of the book Multiculturalism and the Politics of Guilt. Toward a Secular Theocracy (Gottfried 2004).

23 Christians have contributed remarkably to the secularization of the law governing the life of the secular community. "In history-Benedict XVI stated—systems of law have almost always been based on religion: decisions regarding what was to be lawful among men were taken with reference to the divinity. Unlike other great religions, Christianity has never proposed a revealed law to the State and to society, that is to say a juridical order derived from revelation. Instead, it has pointed to nature and reason as the true sources of law-and to the harmony of objective and subjective reason, which naturally presupposes that both spheres are rooted in the creative reason of God. Christian theologians thereby aligned themselves with a philosophical and juridical movement that began to take shape in the second century B.C. In the first half of that century, the social natural law developed by the Stoic philosophers came into contact with leading teachers of Roman Law. (... ). Through this encounter, the juridical culture of the West was born, which was and is of key significance for the juridical culture of mankind. ( ... ) For the development of law and for the development of humanity, it was highly significant that Christian theologians aligned themselves against the religious law associated with polytheism and on the side of philosophy, and that they acknowledged reason and nature in their interrelation as the universally valid source of law." (Benedict XVI 2011). 
all people (John Paul II 1993, 32). Morality itself is treated as a product of man, which can be processed depending on the goals man sets for himself at a given moment in history.

Perhaps in today's world, not only in EU policy, we are seeing a return to the conviction mentioned at the beginning and expressed by Plato that without reference to religion it is impossible to effectively govern society without making it totalitarian. Religion is, therefore, necessary for the political power to survive, and at the same time the temptation of the political elite is to seek that the content and form of (at least) the dominant religion be controlled by this power. It is not about the aggressive secularism or outright hostility to any religion, but about the pursuit of soft control of religion and the actual transformation of religion through real politics. In this context, we should particularly defend freedom of religion and inviolable ethical principles against usurpation by any political authority, constantly reminding all politicians of the above, regardless of the party they come from and notwithstanding at what level: national or the EU, they exercise this power. Paradoxically, celebrations such as the one in Trier, also pose a good opportunity to launch a public appeal for a re-secularization of EU policy.

Cardinal Joseph Ratzinger, analysing the attitude of Jeremiah, the prophet during the siege of Jerusalem, notes that he was convicted and imprisoned due to his pessimism. "The official optimism of the army, nobility, priests, and official prophets demanded that God would guard his city and temple. God was thus relegated to the role of guarantor of human success and used as an excuse for irrationalism." (Ratzinger 2014, p. 439). For it was obvious that in the face of the overwhelming forces of the Babylonians, the attempt of fighting with an unwavering faith in victory was irrational from the military and political points of view. Ratzinger sees the essence of this dispute between the optimists and pessimists as a conflict between "political and irrational theology aimed at ideological power, and the realism of believers who embody morality and political rationality" (ibid). "The criterion of judgment, which Jeremiah gives in verse 9, remains valid: the announcement of success must be judged by empirical criteria, and it cannot be based on theology. Whoever announces today an ultimately idyllic and perfect society of tomorrow must confirm this announcement empirically and must not embellish these remarks with theological arguments. The message about the kingdom of God and about salvation must not be used as proof that certain sociological techniques will produce an intra-historical and therefore empirically functioning society." (ibid, p. 440).

In religions with blunt shafts of criticism, priests "tamed" by politicians will not bring anything significant to the world of politics, and therefore in the long run will be of no use to politicians.

Funding: This research received no external funding.

Conflicts of Interest: The author declares no conflict of interest.

\section{References}

Augustine, Saint. 1887. Epistula ad Probam. Buffalo: Christian Literature Publishing Co., Available online: http://www.newadvent.org/fathers/1102130.htm (accessed on 31 August 2018).

Benedict XVI. 2011. Address at the Bundestag. Berlin. September 22. Available online: http://w2.vatican.va/content/ benedict-xvi/en/speeches/2011/september/documents/hf_ben-xvi_spe_20110922_reichstag-berlin.html (accessed on 16 May 2019).

Bock-Côté, Matthieu. 2019. Le multiculturalisme comme religion politique. Paris: Les Éditions du Cerf.

Bot, Yves. 2011. Opinion of Advocate General Delivered on Case C-34/10 Oliver Brüstle vs. Greenpeace EV. Available online: http://curia.europa.eu/juris/document/document_print.jsf?docid=81836\&text=\&dir= \&doclang=EN\&part=1\&occ=first\&mode=req\&pageIndex=0\&cid=14407648 (accessed on 15 August 2020).

Brague, Rémi. 2018. Sur la religion. Paris: Flammarion.

Chayet, Delphine. 2011. L'agenda européen oublie toutes les fêtes chrétiennes. Le Figaro, December 1. Available online: https:/www.lefigaro.fr/actualite-france/2011/01/12/01016-20110112ARTFIG00673-1-agendaeuropeen-oublie-toutes-les-fetes-chretiennes.php (accessed on 16 May 2019).

Churm, Philip Andrew. 2018. Juncker opens exhibition to Karl Marx. Euronews, May 4. Available online: http://www.euronews.com/2018/05/04/juncker-opens-exhibition-to-karl-marx (accessed on 4 May 2018). 
Cicero, Marcus Tullius. 1829. Of the Nature of the Gods. Oxford: D. A. Talboys. Available online: https: //tinyurl.com/Cicero-Nature-of-Gods (accessed on 3 July 2020).

COMECE (Secretariat of the Commission of the Bishops Conferences of the European Community). 2009. An Overview Report on Bioethics in the European Union. Brussels: COMECE.

Council of Europe. Research Division. 2013. Overview of the Court's Case-Law on Freedom of Religion. Available online: https://www.echr.coe.int/Documents/Research_report_religion_ENG.pdf (accessed on 15 May 2019).

Council of the European Union. 2013. EU Guidelines on the Promotion and Protection of Freedom of Religion or Belief. June 24. Available online: https://eeas.europa.eu/sites/eeas/files/137585.pdf (accessed on 3 September 2018).

European Citizens' Initiative “One of Us”. 2012. Proof of Legal Act. Available online: https://europa.eu/citizensinitiative/initiatives/details/2012/000005_en (accessed on 16 August 2020).

European Commission. 2014. Communication from the Commission on the European Citizens' Initiative "One of Us" COM (2014) 355 Final. Brussels. May 28. Available online: https://ec.europa.eu/transparency/regdoc/ rep/1/2014/EN/1-2014-355-EN-F1-1.Pdf (accessed on 16 August 2020).

European Court of Human Rights. 2011. Arrêt de Grande Chambre Lautsi et autres c. Italie 30814/06. March

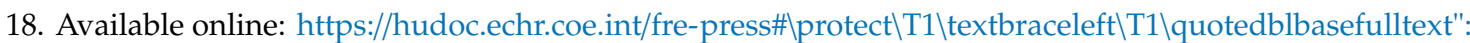
$[\backslash T 1 \backslash$ quotedblbaselautsi"] $\mid$ protect $\backslash T 1 \backslash$ textbraceright (accessed on 15 May 2020).

European Court of Justice. 1996. Judgment of the Court in Case C-84/94, United Kingdom v Council. November 12. Available online: https:/eur-lex.europa.eu/legal-content/EN/TXT/PDF/?uri=CELEX:61994CJ0084\&from=EN (accessed on 15 May 2020).

European Court of Justice. 2011. Judgment of the Court (Grand Chamber) in Case C-34/10. Available online: http://curia.europa.eu/juris/document/document.jsf?docid=111402\&mode=req\&pageIndex $=1 \&$ dir= \&occ $=$ first\&part $=1 \&$ text $=\&$ doclang $=E N \& c i d=14407648$ (accessed on 14 August 2020).

European Court of Justice. 2014a. Action Brought on 25 July 2014-One of Us and Others v Parlement and Others (Case T-561/14). Available online: http://curia.europa.eu/juris/document/document.jsf?docid= $160007 \&$ mode $=$ req\&pageIndex $=1 \&$ dir $=\& o c c=$ first\&part=1\&text=\&doclang=EN\&cid=14736895 (accessed on 16 August 2020).

European Court of Justice. 2014b. Judgment of the Court (Grand Chamber in Case C-364/13, International Stem Cell Corporation vs. Comptroller General of Patents, Designs and Trade Marks. December 18. Available online: http://curia.europa.eu/juris/document/document.jsf?text=\&docid=160936\&pageIndex=0\&doclang= $\mathrm{EN} \&$ mode $=$ req\&dir $=\&$ occ $=$ first\&part $=1 \& \mathrm{cid}=14743277$ (accessed on 16 August 2020).

European Court of Justice. 2017a. Judgment of the Court in Case C-157/15, G4SSecure Solutions. March 14. Available online: https://eur-lex.europa.eu/legal-content/EN/TXT/HTML/?uri=CELEX:62015CA0157\&from= EN (accessed on 15 May 2020).

European Court of Justice. 2017b. Judgment of the Court in Case C-188/15, Bougnaoui and ADDH. March 14. Available online: https:/eur-lex.europa.eu/legal-content/EN/TXT/HTML/?uri=CELEX:62015CJ0188\&from= EN (accessed on 15 May 2020).

European Court of Justice. 2018. Judgment of the General Court (Second Chamber, Extended Composition) in Case T-561/14, European Citizens' Initiative One of Us supported by Republic of Poland vs. European Commission supported by European Parliament and by Council of the European Union. April 23. Available online: http://curia.europa.eu/juris/document/document.jsf?docid=201469\&mode=req\&pageIndex=1\&dir= \&occ $=$ first\&part=1\&text $=\&$ doclang $=E N \& c i d=14736895$ (accessed on 16 August 2020).

European Parliamentary Research Service. 2020. Tracking Key Coronavirus Restrictions on Movement and Social Life. Available online: https://www.europarl.europa.eu/RegData/etudes/BRIE/2020/652018/EPRS_BRI(2020) 652018_EN.pdf (accessed on 3 August 2020).

Ferari, Silvio, ed. 2015. Routledge Handbook of Law and Religion. London: Routledge.

Fox, Jonathan. 2015. Political Secularism, Religion, and the State: A Time Series Analysis of Worldwide Data. New York: Cambridge University Press.

Gagliarducci, Andrea. 2020. Europe and the Challenge of Religious Freedom. July 17. Available online: https://www.janfigel.eu/single-post/2020/07/17/Europe-and-the-challenge-of-religious-freedom (accessed on 4 August 2020).

Geninazzi, Luigi. 2011. In intervista. Frattini: Un martire. L'Europa codarda. L'Avvenire. March 3. Available online: https:/www.avvenire.it/mondo/pagine/frattini-un-martire-leuropa-codarda_201103030737181370000) (accessed on 4 August 2020). 
Gierycz, Michał. 2017. Europejski spór o człowieka (European Dispute over Man). Warsaw: Wydawnictwo Naukowe UKSW.

Gottfried, Paul Edward. 2004. Multiculturalism and the Politics of Guilt. Toward a Secular Theocracy. Columbia and London: University of Missouri Press.

Huntington, Sammuel P. 2005. Who Are We? America's Grat Debate. Sydney: Simon \& Schuster Australia.

John Paul II. 1993. Veritatis Splendor. Available online: http://w2.vatican.va/content/john-paul-ii/en/encyclicals/ documents/hf_jp-ii_enc_06081993_veritatis-splendor.html (accessed on 16 May 2019).

John Paul II. 2000. Message to Cardinal Antonio María Javierre Ortas nn the Occasion of the 1,200th Anniversary of the Imperial Coronation of Charlemagne by Leo III. December 14. Available online: http://www.vatican.va/content/ john-paul-ii/en/speeches/2000/oct-dec/documents/hf_jp-ii_spe_20001216_javierre-ortas.html (accessed on 3 September 2018).

Juncker, Jean-Claude. 2016. Decision of the President of the European Commission of 6 May 2016 on the Special Envoy for the Promotion of Freedom of Religion or Belief outside the EU. Available online: https://www.janfigel.eu/aboutjf (accessed on 3 September 2018).

Juncker, Jean-Claude. 2018. Participation of Jean-Claude Juncker, President of the EC, in the Event Commemorating the 200th Anniversary of Birth of Karl Marx, in Trier: Speech. Available online: https://audiovisual.ec.europa. eu/en/video/I-154723 (accessed on 3 August 2020).

Kłoczowski, Jan Andrzej. 2004. Religia. In Słownik społeczny. Edited by Bogdan Szlachta. Cracow: Wydawnictwo WAM, pp. 1063-80.

Lactantius. 1886. Institutiones Divinae-The Divine Institutes. Edited by Philip Schaff. Available online: http://www.documentacatholicaomnia.eu/03d/0240-0320,_Lactantius,_Divinarum_Institutionum_ [Omnes_Libri_Collecti]_[Schaff],_EN.pdf (accessed on 3 July 2020).

Locke, John. 1983. A Letter Concerning Toleration. Indianapolis: Hackett Publishing Company.

Manon, Simone. 2009. Les trois ordres. Pascal. Available online: https://www.philolog.fr/les-trois-ordres-pascal/ (accessed on 30 August 2018).

Marion, Jean-Luc. 2017. Brève apologie pour un moment catholique. Paris: Grasset.

Maśnicki, Jędrzej. 2013. Godność człowieka w świetle orzeczenia Oliver Brüstle przeciwko Greenpeace EV (c-34/10). Zeszyty Prawnicze 13: 193-210. [CrossRef]

Mazurkiewicz, Piotr. 2011. Procedure de esperienze di dialogo tra confessioni religiose e istituzioni communitarie: Il contributo della COMECE. In Proceedings of the Conferenza Episcopale Italiana, Chiesa e Confessioni Religiose nel Sistema dell'Unione Europea. Atti del Seminario di Studio e di Aggiornamento per i Vescovi Italiani, Roma, Italy, November 14-16; pp. 97-110.

Mazurkiewicz, Piotr. 2017a. Europa jako Kinder niespodzianka (Europe as a Kinder Surprise). Cracow: Ośrodek Myśli Politycznej.

Mazurkiewicz, Piotr. 2017b. Le differend de deux anthropologies dans la politique europeenne. In Penser l'Europe. Les religions et l'identité européenne. Edited by Alina Bălan and Nicoleta Dascălu. Bucarest: Academie Roumaine. Fondation Nationale pour la Science et L'art, pp. 40-52.

Mazurkiewicz, Piotr. 2020. Cultural diversity versus multiculturalism. Christianity-World-Politics 24: 230-50.

Mogherini, Federica. 2015. Intervention at the Conference "Call to Europe V: Islam in Europe", FEPS Conference". Available online: https:/eeas.europa.eu/headquarters/headquarters-homepage_en/ 6332/Federica\%20Mogherini\T1 \textquoterights\%20remarks\%20at\%20"Call\%20to\%20Europe\%20V: \%20Islam\%20in\%20Europe",\%20FEPS\%20conference\%22 (accessed on 25 August 2020).

Motzkin, Gabriel, and Yochi Fischer, eds. 2008. Religion and Democracy in Contemporary Europe. London: Alliance Publishing Trust.

Official Journal of the European Union. 2007. Explanations Relating to the Charter of Fundamental Rights (2007/C 303/02). C 303/17. Available online: https://eur-lex.europa.eu/legal-content/EN/TXT/PDF/?uri=OJ:C:2007: 303:FULL\&from =EN (accessed on 25 July 2020).

Official Journal of the European Union. 2016. Regulation (EU) 2016/679 of the European Parliament and of the Council of 27 April 2016 on the Protection of Natural Persons with Regard to the Processing of Personal Data and on the Free Movement of Such Data, and Repealing Directive 95/46/EC (General Data Protection Regulation). April 27. Available online: https://eur-lex.europa.eu/legal-content/EN/TXT/HTML/?uri=CELEX: 32016R0679\&from=EN (accessed on 16 May 2019). 
Orthodox Times. 2020. Cardinal Charles Bo of Yangon, Myanmar on Hagia Sophia: It Reopens Wounds and Exacerbates Divides. July 28. Available online: https://orthodoxtimes.com/cardinal-charles-bo-of-yangonmyanmar-on-hagia-sophia-it-reopens-wounds-and-exacerbates-divides/ (accessed on 4 August 2020).

Pascal, Blaise. 1958. Pascal's Pensées, Introduction by T. S. Eliot. New York: A Dutton Paperback, E. P. Dutton \& Co., Available online: https://www.gutenberg.org/files/18269/18269-h/18269-h.htm (accessed on 6 July 2020).

Pew Research Center. 2017a. Europe's Growing Muslim Population. Available online: https://www.pewforum. org/2017/11/29/europes-growing-muslim-population/ (accessed on 4 August 2020).

Pew Research Center. 2017b. The Changing Global Religious Landscape. Available online: http://www.pewforum. org/2017/04/05/the-changing-global-religious-landscape/ (accessed on 4 August 2020).

Pius XII. 1947. Letter to President Harry S. Truman. August 26. Available online: https://w2.vatican.va/content/ pius-xii/en/letters/documents/hf_p-xii_lett_19470826_have-just.html (accessed on 28 August 2018).

Puza, Richard. 2012. Effetti dell'ordinamento comunitario sulllo status delle confessioni religiose nei paesi dell'Unione Europea. In Le Confessioni religiose nel diritto dell'Unione Europea. Edited by Laura de Gregorio. Bologna: Il Mulino, pp. 49-62.

Ratzinger, Joseph. 2014. Gesammelte Schriften, vol. 4, Einführung in Das Christentum. Freiburg, Basel and Wien: Herder.

Religare-Eu Project. 2014. Available online: https://ec.europa.eu/programmes/horizon2020/en/news/finding-waysfoster-religious-freedom) (accessed on 3 September 2018).

Respinti, Marco. 2020. The EU Will Have Another Special Envoy for Religious Liberty in the World. Bitter Winter. A Magazine on Religious Liberty and Human Rights in China, September 7. Available online: https: //bitterwinter.org/eu-will-have-special-envoy-for-religious-liberty/ (accessed on 10 October 2020).

Robbers, Gerhard, ed. 1996. State and Church in the European Union. Baden-Baden: Nomos Verlagsgesellschaft.

Salij, Jacek. 2018. Laickie "sakralizacje" prawa stanowionego (Secular 'Sacralization' of the Statutory Law). Chrześcijaństwo-Świat-Polityka 22: 49-56. Available online: https://czasopisma.uksw.edu.pl/index.php/csp/ article/view/3209/2927 (accessed on 25 August 2020).

Schinas, Margaritis. 2020. EU Vice President: I feel angry about what is happening in Hagia Sophia-Turkey to decide where it wants to belong. Orthodox Times, July 24. Available online: https://orthodoxtimes.com/eu-vice-presidenti-feel-angry-about-what-is-happening-in-hagia-sophia-turkey-to-decide-where-it-wants-to-belong/ (accessed on 4 August 2020).

Sowell, Thomas. 2007. A Conflict of Visions. Ideological Origins of Political Struggles. New York: Basic Books.

Sugy, Paul. 2020. Le Conseil d’État rappelle que la liberté de culte est une garantie. Le Figaro, May 18. Available online: https://www.lefigaro.fr/vox/religion/le-conseil-d-etat-rappelle-que-la-liberte-de-culte-estune-garantie-20200518 (accessed on 3 August 2020).

Publisher's Note: MDPI stays neutral with regard to jurisdictional claims in published maps and institutional affiliations.

(C) 2020 by the author. Licensee MDPI, Basel, Switzerland. This article is an open access article distributed under the terms and conditions of the Creative Commons Attribution (CC BY) license (http://creativecommons.org/licenses/by/4.0/). 